\title{
Educational poverty in Italy: concepts, measures and policies
}

\author{
Gian Luca Battilocchi ${ }^{1}$ \\ Recommended citation: \\ Battilocchi, G. L. (2020). Educational poverty in Italy: concepts, measures and policies. Central European \\ Journal of Educational Research, 2(1), 1 - 10.
}

\begin{abstract}
In recent years in Italy, as a result of the initiative by the NGO Save the Children Italia and of the government action, we have witnessed the success of the notion of "povertà educativa", as an effective way to indicate severe inequalities in education across the country. Firstly, the aim of this paper is to shed light on the different concepts and measures of educational poverty in socioeconomic literature, in order to highlight specific and innovative aspects of this idea.

Moreover, the paper intends to scrutinize Save the Children's proposal in order to monitor and tackle educational poverty as well as to show how the action of the NGO has influenced the development of Italian recent government policies against child and educational poverty.
\end{abstract}

Keywords: educational poverty; child poverty; Italy

\section{An emerging problem: child poverty and disadvantage in Italy}

According to the data provided by all major sources of statistical information, the child poverty rate in Italy is substantial and higher than the poverty rate for the overall population. However, the poverty of children and adolescents, that was already showing an upward trend before the onset of the economic crisis (Saraceno, 2015), is diffusely affecting European countries, albeit with marked variability.

To appreciate directly the extent of this phenomenon in Italy, we can refer to the estimate made by the Italian National Institute of Statistics (ISTAT) through the data from national Household Budget Survey. Moreover, we must consider the indicators proposed by EUROSTAT based on EUSILC (European Survey on Income and Living Conditions) data and adopted by the European Union for monitoring and evaluating Member States policies against poverty and social exclusion.

Using household consumption expenditure as an indicator, ISTAT calculates a measure of absolute poverty through the identification of a threshold, which corresponds to the minimum monthly expenditure on a basket of goods and services that a given family deems to be necessary in order to achieve a minimally acceptable standard of living. In 2016 individuals living in absolute poverty amounted to 4.742 .000 , that is $7.9 \%$ of the overall population, but this problem affected 1.292 .000 children, that is $12.5 \%$ of underage population (ISTAT, 2017). Absolute poverty rates amongst children are historically high in Southern regions, but lately this phenomenon has also been spreading to the North as a result of the growing presence of foreign-born households.

Child poverty and deprivation in Italy and in Europe can be further characterized in the light of EU-SILC survey and of some of the key indicators adopted by the European Union under the Europe 2020 Strategy.

${ }^{1}$ Universita Cattolica, Milan, Italy; Gianluca.Battilocchi@unicatt.it 
According to the AROPE indicator of socioeconomic vulnerability ${ }^{2}$, in $201626.4 \%$ of children aged 0-17 lived at risk of poverty or social exclusion in Europe, whereas this percentage was found to be $33.2 \%$ in our country. In both cases these rates are higher than those recorded for the overall population, which stand at $23.5 \%$ in $28-$ member Europe and $30 \%$ in Italy.

Moreover, one of the indicators used to build AROPE refers to the situation of material deprivation, that is understood as the «enforced lack of a combination of items depicting material living conditions, such as housing conditions, possession of durables and capacity to afford basic requirements» (EUROSTAT, 2009, p. 1). The individuals reporting not to have afforded four or more of the nine items listed in the EU-SILC questionnaire during the survey year are considered to be living in 'severe material deprivation'. Also, regarding this indicator, in most European countries the living conditions of children are reported to be worse than those of the overall population. In 2015, the rate of severe material deprivation in Italy was 13\% for children whilst that monitored for the overall population was $11.5 \%$.

The examined indicators do not concern only the income situation but also an experience of deprivation affecting a wide range of goods, services, and opportunities related to different aspects of human life. They reflect an approach to poverty that captures its many facets and connections with social exclusion.

The multidimensional character has been emphasized especially in the study of child poverty: in this case, educational deprivation plays a particular role and the recognition of the availability and abundance, rather than the lack of resources for the development process, is a key factor to understand the living conditions of children. In this perspective, education and learning are parts of a personal experience involved in the impoverishment paths to different degrees.

\section{Educational poverty: traditional and innovative approaches and conceptions}

The expression "povertà educativa" seems to be fairly new in socio-economic literature written in Italian, but the issue of educational poverty has been addressed in a series of studies likely referable to the field of the Economics of Education, using the words "povertà di istruzione".

In the context of a multidimensional view of poverty, education has been interpreted as an essential dimension of wealth or deprivation, and some variables were identified having a crucial bearing on the measurement of this phenomenon: time spent in education, educational qualifications rather than the skill levels assessed by administering standardised tests ${ }^{3}$.

Checchi (1998) suggested an educational poverty measurement strategy based on educational qualifications, recommending to combine absolute and relative measures and to use compulsory education as a key reference point in order to fix a poverty line (although considering effective schooling rates as well).

More recently, Barbieri and Cipollone (2007) have defined educational poverty as a condition characterised by an inadequate proficiency level and have identified as absolute educational deprivation the situation of the fifteen-year olds who didn't reach the lowest skill level in PISA. From the same perspective, a more recent study, using data from INVALSI tests, has provided estimates of multidimensional educational poverty in our country (Minzyuk \& Russo, 2016).

More recently, and with reference to European countries, in the 2015 edition of the Education and Training Monitor, 'educational poverty' is defined by the European Commission as «the share of young people failing to reach minimum standards in education» both in terms of attainment and achievement.

As regards attainment, the indicators used are those supporting the Europe 2020 strategy: the early school leaving rate and the tertiary education attainment share of 30 to 34 year-olds (European

\footnotetext{
2 The at risk of poverty or social exclusion indicator is the headline indicator to monitor EU-2020 poverty target; it consists of three sub-indicators: at risk of poverty rate (i.e. income poverty), severe material deprivation, low work household intensity. People are considered to be AROPE (at risk of poverty or social exclusion) when they experience at least one of the forms of poverty measured by the three sub-indicators.

${ }^{3}$ A recent report provides a brief history of the concept of educational poverty, also accounting for its theoretical economic and sociological premises (Botezat, 2016).
} 
Commission, 2015, pp. 32-46). In order to measure educational achievement at transnational level, in a comparative perspective, the report refers to the proficiency levels in reading, mathematics and science reported in the PISA survey. Underachievement and, as a result, educational poverty has been identified with failure to reach a proficiency level equal to, or greater than, level 2 out of the six established in the survey.

Educational poverty thus defined is associated with some crucial determinants, such as socioeconomic status, family background, home learning environment, migration experience, gender and other structural and institutional factors. According to the data provided mainly by PISA 2012, the Education and Training Monitor, for instance, highlights that in European education and training systems, a low socio-economic status affects participation in non-compulsory education adversely, first of all in early childhood education and care, while a supportive home learning environment influences the development of basic skills positively. Moreover, across Europe, foreign-born students show higher rates of underachievement than native-born, and significant gaps persist also between second-generation and non-immigrant students.

A preceding report by European Commission (2014, pp. 13-14) addressed the issue of educational poverty providing a similar, but more operationalized definition.

Educational poverty can be defined on the basis of the information on degrees and acquired competences. In terms of degrees, poorly educated people are those below secondary level II. In terms of competences, their level of competence remains below level 2.

Also, in this case, educational poverty is identified and measured in terms of both attainment and achievement, making use of data from European Labour Force Survey and, again, from OECDPISA. Educational poverty affects people whose highest level of education attained is at most lower secondary education; moreover, it concerns the low achievers or low performers, as defined by OECD (2016).

This report was drafted by the German sociologist of education Jutta Allmendinger (1999), who introduced the terminology of Bildungsarmut, and some years later, in collaboration with Stephan Leibfried, developed a scheme to identify different concepts and alternative strategies for measuring educational poverty. For this purpose, they distinguished between absolute and relative measures of educational poverty and considered the alternative of choosing between educational qualifications and acquired skills as reference variables; in addition, they suggest to make up both national and international comparison (Allmendinger \& Leibfried, 2003).

Lately, Lohmann and Ferger proceeded in the wake of the works of Checchi and Allmendinger, adopting a relative concept of educational poverty. So, educational poverty is identified as a personal condition characterised by a low level of education deemed unacceptable because it falls below a threshold defined as a minimum in a given society. Educational poverty is not to be understood merely as a descriptive indicator for low education level, but it takes the form of a normative concept, that is a human and social condition requiring targeted social policy as well. More broadly, despite of the narrow link between the concepts of educational poverty and educational inequalities, the authors argue that «from a perspective of social justice, the concept of educational poverty stresses the aspect of inequality of condition while research on educational inequalities focuses mainly on inequality of opportunity» (Lohmann \& Ferger, 2014, p.2). Nonetheless, education is considered in itself not only a specific dimension of personal well-being, but also a resource for social inclusion that enables individual's functionings in a plurality of life dimensions.

\section{The index of educational poverty by Save the children Italia}

The recent success of the expression "povertà educativa" in Italy is primarily due to the multifaceted commitment of Save the Children Italia to investigate and tackle this phenomenon, setting out targets and promoting specific campaign and initiatives. The NGO provides a definition focused on the deprivation of learning and personal growth opportunities, which not only affects cultural resources and cognitive functioning, but also the emotional, relational, and life-planning dimensions: 
... by educational poverty we mean the deprivation of opportunities for children and adolescents to learn, have experiences, flourish and freely develop abilities, talents and aspirations. For a child, educational poverty means being excluded from acquiring those skills needed to live in a world characterized by knowledge economy, by speed and innovation. At the same time, educational poverty means also limited opportunities for emotional and relational development, interpersonal relations and for the discovery of themselves and of the world (Save the Children, 2014, p. 4).

Such a definition is therefore consistent with a multidimensional approach ${ }^{4}$ and emphasizes the circular relationship between economic deprivation and educational poverty.

Save The Children's proposal falls within a theoretical framework, which incorporates both the recommendations made in the well-known Delors Report and the contribution of the capability approach, with a special focus on Martha Nussbaum's version and her list of central capabilities for a life worthy of human dignity (Nussbaum, 2002). Hence, we can identify four basic dimensions of educational abundance or deprivation:

a) learning to understand, or to acquire the skills needed for living in today's world;

b) learning to be, or to enhance motivation, self-esteem and confidence in one's abilities, nurturing aspirations for the future and, at the same time, increasing the ability to control one's feelings even in difficult and stressful circumstances;

c) learning to live together, that is the ability to foster interpersonal and social relationships, to cooperate and communicate, to show empathy and to negotiate. In short, all these capacities that are essential for human beings as social actors;

d) learning to lead an autonomous and active life, to increase one's chances at life and to strengthen health, physical integrity and safety, as well as functional learning conditions. (Save the Children, 2016, p. 5)

Following the contribution of Bakhsi, Hoffman \& Radja (2003), the four pillars of education for the 21st century are seen as a conceptual basis for the adoption of a life-skills (defined as key competencies for everyday life) approach, and used as a framework for the Nussbaum's list of central human capabilities.

Moreover, Save the Children has mechanized the notion of educational poverty by creating a tool for the comparative measurement of the phenomenon, called IPE (Educational Poverty Index). As I will explain, Save the Children's work has proved to be very effective in stimulating policy makers and social workers. However, I think that dealing with the issue of educational poverty is worth further clarification of conceptual and cultural references; such a theoretical framework could function as a basis to develop and refine educational poverty measurement tools.

Within a campaign called "Illuminiamo il futuro 2030", by 2014, Save the Children published its first report on educational poverty in Italy, which contained the findings of the application of the IPE: to measure and compare the phenomenon at the regional level should have suggested targets and action plans in tackling child and educational poverty in Italy (Save the Children, 2014).

The 2014 Index is expressly experimental and organised in two sub-indices each one consisting of seven basic indicators (see Table 1). the first sub-index groups together the indicators related to school context and education system, whilst the second one includes a series of indicators referring to the participation of children in leisure, cultural, and sporting activities provided by the local community.

\footnotetext{
${ }^{4}$ In recent decades, one of the most important development in poverty research is the shift from a uni- to a multidimensional approach (Kakwani \& Silber, 2007).
} 
Table 1. Educational Poverty Index 2014

\begin{tabular}{|c|c|}
\hline $\begin{array}{c}\text { Educational Poverty Index } \\
\text { (IPE) } 2014\end{array}$ & \\
\hline $\begin{array}{l}\text { Sub-Index of } \\
\text { educational poverty } \\
\text { in a school context }\end{array}$ & $\begin{array}{l}\text { 1. Public provision of early childhood education and care services } \\
\text { 2. Full-time classes at primary schools } \\
\text { 3. Full-time classes at lower secondary schools } \\
\text { 4. School complexes with a school meal service } \\
\text { 5. Schools with certificate of occupancy } \\
\text { 6. Classrooms with internet access } \\
\text { 7. Early school leaving rate }\end{array}$ \\
\hline $\begin{array}{c}\text { Sub-Index of } \\
\text { educational poverty } \\
\text { in the local community }\end{array}$ & $\begin{array}{l}\text { 8. Children who have been to the theatre } \\
\text { 9. Children who have been to museums or exhibitions } \\
\text { 10. Children who have visited monuments or archeological sites } \\
\text { 11. Children who have been to a concert } \\
\text { 12. Children who regularly practise a sport } \\
\text { 13. Children who use the internet } \\
\text { 14. Children who have read a book }\end{array}$ \\
\hline
\end{tabular}

Source: Save the Children (2014)

The selected indicators of poverty in a school context are extremely heterogeneous: the items related to the provision are predominant, as in the case of the coverage of early childhood education programmes, the amount and allocation of instruction time, the quality of school infrastructure. The sole indicator focused on student outcome is the "early school leaving rate", that is to say the EU school dropout indicator used under the Lisbon Strategy and still in use in Europe 2020.

The sub-index related to educational poverty in the local community, consisting of indicators based on data from the ISTAT Multiscopo survey appears more homogeneous: it refers to extracurricular activities (like sports, reading books, going to a museum or to a concert) that in many cases could be performed both at school and in social contexts, or within the family environment.

In 2016 Save the Children re-launched regional monitoring and comparison within the same theoretical framework, but a new index was used, characterised by a different calculation technique and a modified set of indicators (Save the Children, 2016). The Index is still organised in two subindices, which are called respectively "Learning and Development" and "Educational Provision" (see Table 2); each of them is related to the targets of the campaign Illuminiamo il Futuro 2030. Despite the substantial modifications of the tool of analysis, the resulting regional rankings continued to highlight the marked gap between the Northern and the Southern regions.

Table 2. Educational Poverty Index 2016

\begin{tabular}{|c|c|}
\hline $\begin{array}{c}\text { Educational Poverty Index } \\
\text { (IPE) } 2016\end{array}$ & \\
\hline $\begin{array}{l}\text { Sub-Index of } \\
\text { learning and development }\end{array}$ & $\begin{array}{l}\text { 1. Low achievers rate in math according PISA texts } \\
\text { 2. Low achievers rate in reading according PISA texts } \\
\text { 3. Early school leaving rate } \\
\text { 4. Children aged } 6-17 \text { who did not participate in four or more out of } \\
\text { seven selected cultural activities }\end{array}$ \\
\hline $\begin{array}{l}\text { Sub-Index of } \\
\text { educational provision }\end{array}$ & $\begin{array}{l}\text { 5. Public provision of early childhood education and care services } \\
\text { 6. Part-time classes in primary schools } \\
\text { 7. Part-time classes in low-secondary schools } \\
\text { 8. Percentage of students who did not benefit from a school meals } \\
\text { service } \\
\text { 9. Percentage of students attending schools without adequate } \\
\text { infrastructure (OECD Index quality of physical infrastructure) } \\
\text { 10. Percentage of classrooms without fast internet access }\end{array}$ \\
\hline
\end{tabular}


Some general remarks can be made to compare the two versions of the Educational Poverty Index in terms of structure and typology of the chosen indicators:

- the number of indicators related to the learning environment and school organization is preponderant in IPE 2016 (while they were less important in IPE 2014). Functional and infrastructural aspects especially are taken into account;

- $\quad$ as far as the most commonly used educational poverty indicators are concerned, in the IPE 2016 the Early School Leaving rate was paired with two proven achievement indicators: the share of low achievers in reading and mathematics measured among 15-year olds within the assessment of the OECD-PISA;

- both indices includes a multitude of indicators related to the participation in cultural and social activities, which are combined into a synthetic indicator in IPE 2016.

On the whole, though its subsequent versions the Educational Poverty Index is therefore characterised by a significant internal heterogeneity, I think it is still struggling to reach a proper synthesis (despite its division into sub-indices). In this regard, anyway, the distinction characterizing the 2014 index between school and social environment seems to be much clearer and thus makes the whole structure more consistent.

\section{What does educational poverty outside the school stand for? The measurability of class effects}

In my opinion, what is new and deserves special attention in Save the children's approach to educational poverty is the importance given to out of school activities and to forms of cultural consumption.

The availability and use of social and cultural resources and opportunities not only has an intrinsic value for the personal growth-process (Eccles, Barber, Stone \& Hunt, 2003), but also produces indirect advantages for school learning (Seow \& Pan, 2014). These experiences not only refer to family background, but they also involve the characteristics of children's broader living environment where the overall provision of services and opportunities depends on a wide range of conditions (political, cultural, economic) and different stakeholders: local authorities, educational institutions, non-profit organizations and associations.

Ensuring children's participation in extracurricular activities has been recognized by Lareau (2011) as a typical feature of the middle-class parenting style. She called it "concerted cultivation", to indicate a process of careful organisation of leisure time and activities, in contrast with working class and poor families logic of child rearing, that she defined "accompanishment of natural growth". Middle-class children would gain from concerted cultivation a comparative advantage, developing cognitive and especially social skills, first of all the ability to act and interact in institutional contexts. Therefore, according to the American sociologist, extracurricular activities would play a crucial role in producing educational inequalities, as a relevant characteristic of family and socio-economic background.

In a recent study about social inequalities in school systems, Bonini (2012) suggested to use a cultural consumption index as proxy of socio-economic status. In her view, the choice of considering cultural consumption rather than home possessions (namely the material and cultural resources available in the home environment), that are usually considered in international and national surveys (in PISA as well as in INVALSI questionnaires in Italy), would allow for a better understanding of the effects of family background on learning. This proposal seems to the scholar more consistent with a theoretical framework that acknowledges the increasing emphasis on the role of consumption in contemporary social dynamics and in the construction of identity. Meanwhile, it can be referred to by Bourdieu's concepts of practice and cultural capital as a proxy of the social condition of an individual (Bonini, 2012, p. 151). 


\section{The influence of Save the Children Italia on the development of policies against child poverty and educational poverty in Italy}

During the seventeenth parliamentary term, a set of measures was adopted in Italy, aimed at reducing child monetary and educational poverty; these measures appear, to varying degrees, to be traceable to the attention raised by Save the children to the living conditions of childhood and adolescence in Italy.

Both child poverty and educational poverty were in fact included in the national policy agenda, and took the form of income support measures for household with children and of a pioneering and experimental effort to tackle educational poverty.

In 2014 the Parliamentary Committee on Childhood and Adolescence promoted a study aimed at investigating child poverty. The final report paid also particular attention to the issue of educational poverty, assuming a multidimensional concept inclusive of formal, non formal and informal aspects of education. The report acknowledged expressly the relevance of the findings from the implementation of the IPE, although highlighting the shortcomings and the desirability of a future development and refinement of the new tool.

The guidelines resulting from the document have been translated into some government measures. 2016 financial law established a "Fund for fighting poverty and social exclusion" and identified two goals concerning the use of these resources:

- the launch of a measure (called 'SIA', that stands for 'Support for Active Inclusion') to support the income of households with children, especially lone parent families and larger households;

- the payment of 'ASDI', an unemployment benefit mainly intended for households with children.

Since September 2016, SIA program has guaranteed an economic benefit to poor families with children who meet any conditions: recipients must sign an integration contract and participate in tailored projects aimed at overcoming poverty and social exclusion. This measure has been especially innovative in the national policy scenario since it establishes for the first time in Italy a selective universalistic and active form of income support. Coupled with ASDI, this provision contributed to create a specific strategy for fighting against child poverty in a substantially unprecedented way in our country.

Moreover, within the framework of FEAD (Fund for European Aid to the Most Deprived) Programme for 2014-2020, which provided non-financial assistance to most vulnerable people in all European member states, Italy decided to address material deprivation of children and adolescents in school context, as well as educational poverty of children in disadvantaged areas throughout the country. So, the Programme provided for the allocation of school supplies to students living in poor families such as recipients of SIA; furthermore, resources have been assigned to schools in deprived areas, to provide meals and afternoon openings. Once again, to support this choice, the Programme expressly refers to the activity of investigation and monitoring carried out by Save the Children.

In addition to measures against income poverty and material deprivation, a special "Fund against childhood educational poverty", aimed at financing projects developed by schools and third sector organisations, has been established on an experimental level over the three-year period from 2016 to 2018 (with 120 million euros per year). The Fund is fuelled by banking foundations that become thereby eligible for a tax credit. In April 2016 a Memorandum of Understanding was signed by the Presidency of the Council of Ministers, ACRI (the Italian Association of Saving Banks and Foundations), and the Third Sector Forum. The document sets out the goals of the Educational Poverty Fund, generally "aimed at removing economic, social and cultural obstacles that prevent children from fully benefiting from the educational process".

In October 2016, two calls were published for the development of projects targeted respectively to poor adolescents and children. The overall objective of the first announcement has been identified in the reduction of school drop-out rates among young people aged 11-17. Following a welfare community perspective, drafts should have been presented by partnerships including schools and third sector organisations; they should be articulated in different actions, with the twofold purpose 
of improving school success and promoting soft skills, a result deemed crucial for general child wellbeing.

The second announcement was generally aimed at strengthening the provision of childhood education and care services (that is to say promoting access, differentiating the supply and encouraging integration among social assistance, health system and educational services), paying special attention to the most vulnerable children and households, and to disadvantaged areas.

Lately, in 2017, a third call was published named "New generations", addressed to children aged 5-14. Once more, public-private partnerships, including especially schools and third sector organisations, have been invited to submit exemplary projects aimed at promoting child well-being, by giving priority to more vulnerable children and adolescents in disadvantaged areas. Drafts should take an integrated and preventive approach and consider actions inside and outside schools, promoting the resources available in the community 5

\section{Conclusions}

The concept of educational poverty appears to strengthen the theoretical and analytical link between poverty and education: not only education is deemed an essential dimension of well-being, but also a relevant focus is on the mutual impact of economic strain and educational opportunities and outcomes.

Furthermore, Save the Children's perspective is in itself consistent with a multidimensional view. The IPE takes into account both formal and informal education, extracurricular activities and school experience; moreover, indicators are used concerning the functioning of school systems, but also students' attainment and achievement levels. This is in my opinion a relevant development in conceptualizing and measuring educational poverty.

A multidimensional view entails complex measurement tools: the use of indices seems particularly suitable because of the articulation and synthesis of a plurality of domains and indicators. A crucial requirement for this kind of tool should be a conceptual model to establish the selection and organisations of domains and indicators. Moreover, as Belotti and Moretti (2000, pp. 9-12) point out, data that is not collected ad hoc but is available within different research or administrative frameworks, is not in all likelihood reliable to set up a synthetic measurement instrument. Save the children's IPE, although its value as a boost to social policy development, requires probably an additional effort of clarification towards a conceptual scheme that constitutes the basis for ad hoc data collection.

With the implementation of a comprehensive strategy to fight against child poverty, which expressly addresses educational poverty, Italy has proved to be able to mobilise additional public and private resources through a wide and original governance. This policy strategy is still in progress and it has been partly revised as regards income support; however, monitoring and in depth evaluating the new measures will be crucial to the establishment of structural and effective policies that produce real changes in children's and households' living conditions in Italy.

Acknowledgments: I would like to express my gratitude to Elena Besozzi who has encouraged my efforts since the very early stages and to Maddalena Colombo who enriched this work with her precious suggestions and remarks.

\footnotetext{
5 It seems reasonable to place all those measures in the framework of the Social Investment Package (European Commission, 2013b) which includes also the Recommendation Investing in children. Breaking the cycle of disadvantage (European Commission, 2013a). A social investment strategy implies qualifying people's skills in order to strengthen participation in society and in the labour market, addressing specific needs throughout the life cycle, from a highly preventive perspective. The European Commission especially invites member states to pursue activating and enabling policies through conditional support and to invest in children in an integrated way, with a combination of social assistance, high quality education, health promotion.
} 


\section{References}

1. Allmendinger, J. (1999). "Bildungsarmut". Zur Verschränkung von Bildungs-und Sozialpolitik. Soziale Welt, 50 (1), 8-9.

2. Allmendinger, J. \& Leibfried, S. (2003). Education and the welfare state: the four worlds of competence production. Journal of European Social Policy, 13 (1), 63-81

3. Barbieri, G. \& Cipollone, P. (2007). I poveri in istruzione. In Brandolini, A. \& Saraceno, C. (Eds.), Povertà e benessere. Una geografia delle disuguaglianze in Italia (pp. 329-349). Bologna: Il Mulino.

4. Belotti, V. \& Moretti, E. (2000). L'Italia minore. Mappe di indicatori sulla condizione e le disuguaglianze nel benessere dei ragazzi e delle ragazze. Firenze: Istituto degli Innocenti

5. Bonini, E. (2012). Scuola e disuguaglianze. Una valutazione delle risorse economiche, sociali e culturali. Milano: Franco Angeli.

6. Botezat, A. (2016). Educational poverty. NESET II Ad Hoc Question, 5. Retrieved from http://nesetweb.eu/wp-content/uploads/2016/02/AHQ5_Educational-Poverty.pdf

7. Checchi, D. (1998). Povertà e istruzione: alcune riflessioni e una proposta di indicatori. Politica economica, 14 (2), 245-282.

8. Commissione Parlamentare per l'Infanzia e l'Adolescenza XVII Legislatura. (2014). Indagine conoscitiva sulla povertà $e$ il disagio minorile. Roma Retrieved from: http://documenti.camera.it/leg17/resoconti/commissioni/stenografici/pdf/36/indag/c36_poverta/2014/12/1 6/leg.17.stencomm.data20141216.U1.com36.indag.c36_poverta.0023.pdf

9. Eccles, J.S., Barber B.L., Stone, M., \& Hunt, J. (2003). Extracurricular activities and adolescent development. Journal of social issues, 59 (4) 865-889.

10. European Commission. (2013a). Investing in children. Breaking the cycle of disadvantage, Bruxelles. Retrieved from https://eur-lex.europa.eu/legal-content/EN/ALL/?uri=CELEX:32013H0112

11. European Commission. (2013b). Towards Social Investment for Growth and Cohesion - including implementing the European Social Fund 2014-2020. Bruxelles. Retrieved from: https://ec.europa.eu/eip/ageing/library/towards-social-investment-growth-and-cohesion-includingimplementing-european-social-fund_en

12. European Commission. (2014). An ever closer union among the peoples of Europe? Rising inequalities in the EU and their social, economic and political impacts. Outcomes of EU-funded research. Luxembourg: Publications Office of the European Union.

13. European Commission (2015). Education and training. Monitor 2015. Luxembourg: Publications Office of the European Union.

14. Eurostat (2009). What can be learned from deprivation indicators in Europe. Luxembourg: Publications Office of the European Union.

15. International Commission on Education for the Twenty-first Century. (1996). Learning: the treasure within. Paris: UNESCO Publishing

16. ISTAT (2017). La povertà in Italia. Anno 2016. Roma: ISTAT. Retrieved from http://www.istat.it/it/archivio/202338.

17. Kakwani, N. \& Silber, J. (Eds.). (2007). The many dimensions of poverty. New York: Palgrave Macmillan

18. Lareau, A. (2011). Unequal childhoods. Class, race and family life. Second Edition. With an update a decade later. Berkeley-Los Angeles: University of California Press.

19. Lohmann, H. \& Ferger, F. (2014). Educational poverty in a comparative perspective: theoretical and empirical implications. SFB 882 Working Paper Series, 26. Bielefeld: DFG Research Centre Retrieved from https://pub.uni-bielefeld.de/publication/2651911

20. Minzyuk, L., \& Russo, F. (2016). La misurazione multidimensionale della povertà in istruzione in Italia. Politica economica, 23 (1) 65-122.

21. Nussbaum, M. (2002). Giustizia sociale e dignità umana. Bologna: Il Mulino.

22. OECD (2016). Low-Performing Students: Why They Fall Behind and How to Help Them Succeed. Paris: OECD Publishing.

23. Radja, K., Hoffman, A.M., \& Bakhsi, P., (2003). Education and the capabilities approach: Life skills education as a bridge to human capabilities. Paper presented at the Third Conference on Capability approach. Retrieved June 6, 2016, from http://ethique.perso.sfr.fr/

24. Saraceno, C. (2015). Il lavoro non basta. La povertà in Europa negli anni della crisi. Milano: Feltrinelli

25. Save the Children (2014). La lampada di Aladino. Roma: Save the Children Italia 
26. Save the Children (2015). Illuminiamo il futuro 2030. Obiettivi per liberare i bambini dalla povertà educativa. Roma: Save the Children Italia

27. Save the Children (2016). Liberare i bambini dalla povertà educativa. A che punto siamo?. Roma: Save the Children Italia

28. Seow, P. \& Pan, G. (2014). A literature review of the impact of extracurricular activities participation on students' academic performance. Journal of education for business, 89 (7) 361-366.

(C) 2020 by the authors. Submitted for possible open access publication under the terms and conditions of the Creative Commons Attribution (CC BY) license (http://creativecommons.org/licenses/by/4.0/). 